VÍT BOČEK

Czech Academy of Sciences, Brno

vitbocek@gmail.com

\title{
THE ETYMOLOGY OF THE SLAVONIC NAME FOR ERMINE (MUSTELA ERMINEA) I: MATERIAL AND EXISTING THEORIES'
}

Keywords: Slavonic etymology, ermine, ${ }^{\star}$ gornostajb ${ }^{*}$ gornostalb

\begin{abstract}
The author introduces the Slavonic material leading to the reconstruction of Common Slavonic * gornostajb/ ${ }^{*}$ gornostalb 'ermine, Mustela erminea' and discusses the existing etymological explanations of the word.
\end{abstract}

\section{Introduction}

The present text is the first part of a paper devoted to the etymology of Common Slavonic * gornostajb/* gornostalb 'ermine, Mustela erminea', the name for a species of the family Mustelidae. So far, no convincing etymology of this word has been proposed. ${ }^{2}$ Since the Common Slavonic origin is generally assumed, I will first present the attested material from individual Slavonic languages leading to the reconstruction of the Common Slavonic word. Then, a critical overview of the existing etymologies of this word will be given in order to obtain a basis for a new explanation, which will be presented in the second part of the paper, published separately.

1 The paper was written with the support of a grant from the Czech Science Foundation (No. 18-02702S). I thank Tatjana Šalajeva (Moscow), Marek and Kamil Stachowski (Krakow) for helping me with some references, and Václav Blažek (Brno) for useful comments.

2 Several researchers simply judge the Slavonic word as etymologically unclear or obscure (cf. Miklosich 1886: 74; Torbiörnsson 1901-1903, 2: 27; Berneker 1908-1914, 1: 332; Schrader, Nehring 1927-1929, 2: 158; Vasmer 1953-1958, 1: 297; KESRJ: 81; Shevelov 1964: 405; ESRJ, I/4: 138). 


\section{Material and reconstruction}

The following attested forms are available to aid in the reconstruction of the original Common Slavonic word: dialectal Slovene gránoselj, grájneželj, gránezelj, gránoslek 'weasel' (Bezlaj 1976-2007, 1: 170), gránezelj 'weasel', 'ear-to-mouth beard' (Pleteršnik 2006, 1: 244), '3lovak hranostaj 'ermine, Mustela erminea', 'fur of ermine' (SSSJ, 2: 169), dialectal Slovak ranostaj 'ermine, Mustela erminea' (SSN, 1: 618), Old Czech hranostaj 'ermine, Mustela erminea', 'fur of ermine' (Gebauer 1903-1916, 1: 186; Šimek 1947: 52), Czech hranostaj 'ermine', 'fur of ermine' (PSJČ: 959), dialectal Czech chramostejl, chramostýl 'ermine' (Kott 1878-1893, 1: 540), Old Polish gronostaj 'ermine', 'fur of ermine' (SS, 2: 496), ${ }^{4}$ Polish gronostaj 'ermine', 'fur of ermine’ (SłJP, 2: 1310), dialectal Polish gronostal, gronostål 'ermine', 'fur of ermine' (Boryś 2005: 179), ${ }^{5}$ Ukrainian hornostáj 'ermine, Mustela erminea', 'fur of ermine' (SUM, 2: 134), obsolete and dialectal Ukrainian hornostáj 'a kind of bird' (Hrinčenko 1907-1909, 1: 313), ${ }^{6}$ hornostál' 'ermine' (Hrinčenko 1907-1909, 1: 313), Old Belorussian hornostaj 'ermine' (HSBM, 7: 84), Belorussian harnastáj 'ermine', 'fur of ermine' (TSBM, 2: 32), Old Russian gornostaj 'ermine', 'fur of ermine', 'a kind of tax' (Sreznevskij 1893-1903, 1: 554; SDRJ, 2: 357; SRJ, 4: 89), ornostaj 'ermine', 'fur of ermine' (Sreznevskij 1893-1903, 2: 707; SRJ, 13: 69), gornostalb 'ermine', 'fur of ermine' (Sreznevskij 1893-1903, 1: 554; SRJ, 4: 89), Russian gornostáj 'ermine', 'fur of ermine', dialectal Russian gornostár', gornostál', gornostálin, gornostán' 'ermine' (SRNG, 7: 50-51). ${ }^{7}$

Some forms are probably the results of various secondary changes. Czech dialectal words were apparently associated with the verb chramostiti 'to rustle' (Gebauer 1894-1929, 1: 373). Similarly, the second part of Slovene words underwent changes due to folk etymology (Sławski 1952-1982, 1: 351). East Slavonic words are usually

Moszyński (1956: 112) and Blažek (1992: 58-60) give only an overview of extant hypotheses, with no conclusion for any of them.

3 Bezlaj (1976-2007, 1: 170) cites also Slovene gornostâj 'Mustela erminea' as an alleged borrowing from Russian. I did not find it in any other source.

4 In addition, SJP (1: 913) cites Old Polish hronostaj and hornostaj. In SJP (2: 55, 58), hornostaj is explained as a borrowing from Ukrainian or Belorussian and hronostaj as a secondary formation from hornostaj. According to Miklosich (1886: 74) and Berneker (1908-1914, 1: 332), both forms were borrowed from Ukrainian. To my knowledge, these forms are not present in any other sources. Thus, their very existence is uncertain. - Several Old Czech and Old Polish glosses (Old Czech hranostay, Old Polish gronost(h)ay) are translations of the Medieval Latin variants migale, micale, mitale, megale, merhale, or iugale, which originated from the Greek zoological term $\mu v \gamma \alpha \lambda \tilde{\eta}$, originally designating another animal, the common shrew (Sorex araneus). Thus, Slavonic forms attest to the transfer of meaning in Latin words from 'shrew' to 'ermine' (see Šedinová 2015 for details).

5 In addition, SJP (1: 913) cites dialectal Polish hronostaj, hornostaj. The existence of these forms is uncertain, cf. footnote 4.

6 The possibilities of semantic development from ermine to a bird are discussed by Železnjak (1995: 59-60): either we can see the similar cry of the two animals as the tertium comparationis, or there was simply a shift of meaning from 'ermine' to 'weasel', the latter being expressed also by the word laska, a homonymous form, designating also a specific kind of bird, the swallow.

Bulgarian gornostáj 'ermine' is a borrowing from Russian (Damerau 1960: 79), as well as obsolete Serbo-Croatian gornòstaj 'ermine' (RSKNJ, 3: 488). 
seen as secondary formations in which original polnoglasie was lost (cf. Sobolevskij 1962: 98; Orel 2007-2011, 1: 269) either by syncope in rapid speech (Havlová 2010: 143), or by association with the adjective górnyj 'mountain' (cf. Torbiörnsson 1901-1903, 2: 27; Berneker 1908-1914, 1: 332; also Brandt 1889: 123 as a possibility). Another possible solution is to explain East Slavonic words as primitive formations in which polnoglasie never occurred, i.e. as the results of a variability or an inconsistence of this sound development (this is suggested by Brandt 1889: 123; relatively rich East Slavonic material without the expected polnoglasie has been tentatively gathered by Witkowski 1999).

With respect to these secondary changes and the variability in the end of the words in individual Slavonic languages, the original form of the Common Slavonic word is hard to determine. Mostly, two Common Slavonic forms are reconstructed, ${ }^{*}$ gornostajb and ${ }^{*}$ gornostalb. ${ }^{8}$

\section{Existing theories: overview and discussion}

Up to the present, the following etymological explanations of the word have been given:

(1) The Common Slavonic word is mostly seen as a borrowing of a Germanic compound. The first to assume this origin was Šapir (1872: 19-21), who quoted the Middle High German hermezagel 'ermine's tail' and presupposed its Old Saxon cognate *harmestagl, which would develop to *harmastal > thornostal and eventually be adopted into Slavonic as ${ }^{\star}$ hornostalb. The Germanic origin was accepted by Gorjajev (1896: 75). According to Preobraženskij (1910-1949, 1: 148), the original Slavonic form of the borrowing was ${ }^{*}$ gormestalb; only later was it changed to *gornostalb under the influence of górnyj 'mountain'; the Czech and Polish words are borrowings from Russian. In several later works, the assumed Old Saxon *harm(en)es-tagl/ harmenes-tail 'ermine's tail' is commonly cited as the most likely source (cf. ESSJ, 7: 48-49; ESBM, 3: 62; ESUM, 1: 569; SP, 8: 119-120; Orel 2007-2011, 1: 269; Havlová 2010: 143; Králik 2015: 208; with some hesitation also Sławski 1952-1982, 1: 351 and Rejzek 2015: 235). ${ }^{9}$

The Germanic compound can be further etymologized as follows. The first component is the Germanic *harman- 'ermine' (> Old English hearma 'shrewmouse', Old Saxon harmo 'ermine', Old High German harm(o) 'weasel; ermine'; cf. Kroonen 2013: 212; for more widely attested derivatives, see EWA: 833-835 and 984-986). With this Germanic word, Baltic expressions can be compared: Lithuanian šarmuõ 'wildcat; ermine; weasel', dialectal šermuõ 'ermine; weasel',

8 Černych (1993, 1: 206) speculates that the original form might have been * gornostavø and later developed to * gornostavjo $>{ }^{*}$ gornostajb.

9 An improbable solution was proposed by Abajev (1958-1989, 3: 143-144) who explained the Slavonic compound as a crossing of Germanic *harman- 'ermine' and Scythian staj 'lynx' (< Indo-Iranian ${ }^{\star}$ stāyu- 'thief'). 
derivatives: Lithuanian šarmonỹs 'weasel', Latvian sarmulis 'ermine; weasel; rabbit', sermulis 'ermine', and others (cf. Smoczyński 2007, 1: 631; Derksen 2015: 445). ${ }^{10}$ From this material, the Indo-European nominal root ${ }^{\star} k$ 'orm-/ ${ }^{*} k$ 'erm-can be reconstructed, belonging to the Indo-European ablauting root ${ }^{\star} k^{\prime}$ or- ${ }^{*} k^{*}$ 'er-, designating dark and grey tones (Pokorny 1959-1969, 1: 573). ${ }^{11}$ The second component of the Germanic compound is the Germanic ${ }^{\star}$ tagla'hair, fur' (> Old Norse tagl 'horse's hair, tail', Old English toegl 'tail', English tail 'tail', Old High German zagal 'tail, sting, penis', Gothic tagl 'hair'; cf. Kroonen 2013: 504).

The explanation that the Slavonic word was borrowed from Germanic has formal as well as semantic difficulties. Formally, an irregular sound substitution must be accepted: Slavonic $g$ for the Germanic $h$ (instead, $x$ would be expected for the Germanic $h$ in the oldest layer of Germanic borrowings into Slavonic, cf. Rejzek 2008: 25-26, and later $h$, cf. Newerkla 2011: 52, 54 and passim). Semantically, it is not quite clear why the word for an animal in the recipient language should be motivated by the word for a part of the body of the same animal in the source language. One possibility is that the Germanic compound meant 'ermine's fur' as a kind of currency (cf. Boryś 2005: 180) or a kind of wares. Trade in ermine furs is documented in the areas where the Hanseatic League was active. According to Bańkowski (2000, 1: 482), ermine furs were imported mainly from Novgorod over Riga to Polish and then to German towns. Therefore, the author presupposes - in a similar vein as Preobraženskij (cf. above) - the adoption of the Germanic expression into Old Russian first, and only from there to Old Polish. He maintains that Czech hranostaj is a learned expression, with a pseudo-bohemization of Polish grono- to hrano-. The existence of Old Czech records that are older than Old Polish records weakens this part of the author's hypothesis, but the main thought about the spread of the word from East to West remains intact. In this context, it is also worth noting that the Old Czech records more often have the meaning 'fur of ermine' than 'ermine'. Be that as it may, the formal problem concerning sound substitutions has not yet been solved by any adherent of the Germanic origin and this explanation has been rejected by many scholars (cf. Vasmer 1953-1958, 1: 297; KESRJ: 81; ESRJ, I/4: 138).

10 Some add also Rhaeto-Romance carmun 'weasel' and Old Indic srmará- 'an animal living in wet places'. The former seems more plausible than the latter (cf. HR, 1: 155; Mayrhofer 1956-1976, 3: 500).

11 A continuation of this root in Slavonic is often seen in the East Slavonic word for wolverine: Russian rosomácha, rossomácha (with alleged metathesis), dialectal Ukrainian soromácha, dialectal Belorussian saromácha $<$ Common Slavonic *sorm-acha, with *sorm-as the regular Slavonic continuant of Indo-European ${ }^{*} k$ 'orm- (Polish rosomak and Czech rosomák are borrowings from Russian; see Havlová 2010: 138-139 with a discussion of other explanations of the East Slavonic forms). Recently, Blažek (2017: 56), developing on older suggestions made by Sobolevskij, explains Russian forms without the assumption of metathesis. The author presupposes a haplology ${ }^{*} \operatorname{ros}(V)$-sorom ${ }^{\circ}<{ }^{*} r b s(V)-\operatorname{sorm}^{\circ}$ and in the first part of the word, ${ }^{*} r b s b$, he sees Slavonic evidence of the Indo-European ${ }^{*} \mathrm{H}_{2 \mathrm{o}} r t k^{\prime} \mathrm{o}-{ }^{*}{ }^{*} \mathrm{H}_{2 \mathrm{r}} \mathrm{rdk}$ 'o- 'bear', here bearing an augmentative meaning. The word for wolverine would then originally mean 'bear ermine,' 
(2) According to other scholars, the first part of the Slavonic word is genetically related to the above-mentioned Baltic and Germanic words (cf. Bezlaj 1967: 147; Bezlaj 1976-2007, 1: 170). The second part is then explained variously by different scholars:

a. According to Machek (1957:143 = Machek 1968: 183), if $-l$ is primitive in the second part, it could be connected with Latin müstella, müstēla 'weasel' (for the etymology of Latin word, see Vaan 2008, 1: 396-397). He therefore assumes the original meaning of the Slavonic word as 'ermine weasel'. This explanation was adopted by Holub and Lyer (1967: 197-198).

b. Agrell (1919: 43-44) connected the second part of Slavonic word, * stario-, to Lithuanian stãras 'sisel, suslik, hamster'. The etymology of the Lithuanian word is, however, uncertain (see Fraenkel 1962-1965, 2: 896).

c. Šapira (2007:30) speaks a bit enigmatically about a "Germano-Irano-Russian compound" with the meaning 'ermine', and cites Russian gornostáj, Gothic hormo (which is, however, unattested) and Scythian stay 'lynx'.

The assumption of relatedness of the first part of the Slavonic word with Baltic and Germanic words presents another formal difficulty. This time it is necessary to admit a variability of the initial consonant in the Indo-European root: ${ }^{*}$ gor- $\left.\right|^{*}{ }^{*}{ }^{\prime}$ or(Machek's and Bezlaj's view), or, alternatively, a secondary sporadic change ( $k^{\prime}>$ ) $k>g$ in Slavonic (Agrell's view; in a similar vein cf. also Matzenauer 1880: 191-192).

(3) A somewhat neglected etymology was proposed by Železnjak (1995). The author sees as the main motivation for naming ermine its bad smell. She reconstructs Common Slavonic *gorns 'stink, bad smell', ' gorniti 'to smell, to stink' ( dialectal Ukrainian góryč 'sharp smell originating at the process of fermentation of cabbage' and several dialectal Ukrainian personal names). As far as the second part of the compound is concerned, she maintains that - stajo $\left(<{ }^{*}\right.$ stati, *stojati 'to state, stand') meant 'state, essence in general', and that in compounds, the first part in turn expressed some specific state, essence, quality, or attribute (see also Železnjak 1994 for other Slavonic compounds with -stajb, -stojb). The name for ermine would then originally mean 'an animal that stinks or keeps smelling bad'. According to the author, the original form was ${ }^{*}$ gorno-stajo and only later was the connecting element changed to -o- under the influence of the adjective ${ }^{*}$ gornz/ ${ }^{*}$ gornzjs 'mountain'. The explanation finds good semantic parallels in other names of species belonging to the family Mustelidae: cf. Common Slavonic ${ }^{\star} d z c h o r^{\prime} b$ 'an animal with stinking breath' $\left(\sim \sim^{\star} d z c h n o t i\right.$ 'to breathe, smell, stink'), Latin foetorius 'ermine' ( foetor 'stink, stench'), Latin putorius vulgaris 'weasel' ( $\sim$ püteō 'to stink, smell') and others. The weak point of the explanation is, however, the scant evidence of continuants of the alleged Common Slavonic *gorno 'stink, bad smell'.

that is, 'big ermine'. However, the author does not explain why would this augmentative 'bear'-component be present in Russian only and not in dialectal Ukrainian and Belorussian words for wolverine. 
(4) Černych $(1993,1: 206)$ proposed another solution, based on the assumption that the first part of the compound, ${ }^{*}$ gorno-, was the same as in Common Slavonic *gorěti 'to burn' (< Indo-European * ${ }^{*}$ "her- 'warm, hot'; cf. Pokorny 1959-1969, 1: 493-495), and thus referred to the colour of the ermine's summer fur, with various tones of brown, from light to dark. The second part was interpreted similarly as by Železnjak, though rather implicitly. Thus, the compound would originally mean 'an animal whose fur has warm colour tones'.

Other explanations are far from plausible:

(5) Il'jinskij (1911: 7-8) saw in the first part of the Slavonic word an onomatopoeic root *gorn-, which is present in Old Church Slavonic granz 'verse, stich', Old Czech hrana 'knell, toll, passing-bell', Lower Sorbian groniś 'to speak, talk', Polabian gornĕt 'to speak, talk', etc. The author connected this material with Old Indic járatē 'he sounds, calls, murmurs', Lithuanian garrsas 'sound', Irish gairm 'shout, cry' (for an overview of competing etymological explanations of the mentioned Slavonic material, see ESJS, 4: 200-201). For the end of the word, the author proposed specific means of word formation and sound development for individual forms attested in Slavonic languages. According to him: (a) Slovene forms are l-diminutives of original ${ }^{\star}$ gran-ezz, with suffix -ez-; (b) two Common Slavonic verbs, ${ }^{*}$ gorn-oz-iti and ${ }^{*}$ gorn-ot-ati crossed each other and gave rise to ${ }^{*}$ gornoztati $>{ }^{*}$ gornostati 'to cry'; from it, Common Slavonic ${ }^{*}$ gornostajb with the suffix -jb- and ${ }^{\star}$ gornostarjb with the suffix -arjb- (with subsequent dissimilation to -aljb) were derived.

(6) Holub and Kopečný (1952: 132) saw in the first part the root * gorn- 'top, high, upper; up' ( Slavonic * gora 'mountain', etc.). According to them, ${ }^{\star}$ gorno-stajb would mean 'animal that rises against a human aggressor'. This etymology is followed by Rudnyc'kyj (1966-1967, 1: 698).

(7) Brückner (1957: 158-159) associated the first part with the root represented by Common Slavonic ^žero, “žbrati 'to eat (greedily), guzzle' ( $<$ Indo-European ${ }^{*} g^{u}$ er- 'to devour, guzzle'), without giving any details concerning the presumed motivation for the designation.

(8) Loewenthal (1920: 378-379) found three possibilities: (a) ${ }^{*} g^{u}$ ornostó-s, with the Indo-European root ${ }^{*} g^{u}$ or- 'mountain, forest' ( Common Slavonic ${ }^{*}$ gora 'moun-

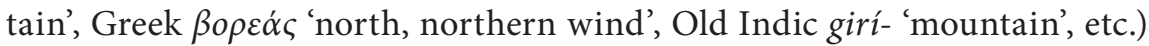
and alleged meaning 'dark, dark brown'; (b) * ${ }^{*} g^{u}$ ornàt-stốii-s, with the first part containing Indo-European ${ }^{*} g^{u}$ er- 'to devour, guzzle', the second part related to Russian dialectal stája 'stable', Lithuanian stáine 'stable for horses', and with the alleged meaning 'Stahlfresser', i.e. probably, 'eater in the stable'; (c) * $g^{u}$ ornostó-s

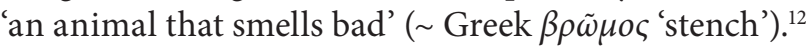

12 The Greek word is, however, without clear etymology, and in Greek etymological treatises, Loewenthal's connection with the Slavonic word for ermine is not even noted, cf. Beekes (2010, 1: 246). 
(9) Loewenthal (1924: 180) proposed yet another solution: ${ }^{*} g^{u}$ oro-nas-tấíio-s 'an animal with a pointed nose' (< Indo-European ${ }^{\star} g^{u}$ ere- ‘to be pointed, sharp, keen').

(10) Räsänen (1953: 17-18) saw dialectal Russian gornostár' as the primary Slavonic formation and wanted to explain it as a borrowing of Yakut kyrynās (a form that he interpreted as kyryn 'to turn, turn back to a former place' + Turkic ās 'ermine') + plural ending -tar. Alternatively, he offered Ostyak xarńi sas 'ermine, weasel' as the source of the Slavonic word and considered Yakut kyrynastai a back borrowing from Russian. The author's suggestions are rather unclear and went unnoticed in Slavonic etymological literature. Both the Yakut word and its Dolgan counterpart kyrynās 'ermine' are probably loanwords from Russian (cf. Slepcov 1964: 58, 67, 183; Stachowski 1998: 180; 1999: 98).

\section{Recapitulation}

To summarize, the researchers have tried to find a motivation for naming the ermine in Slavonic in the colour of its fur (cf. (1), (2), (4), (8a)), in its stink (cf. (3), (8c)), cry (cf. (5)), nose shape (cf. (9)), and alleged behaviour (cf. (6), (7), (8b). In the upcoming part of the paper, these motivations will be briefly discussed again and, based on this, a new etymological solution will be proposed.

\section{References}

Abajev V.I. 1958-1989. Istoriko-etimologičeskij slovar' osetinskogo jazyka. [6 vols.]. Moskva, Leningrad.

Agrell S. 1919. Baltoslavische Lautstudien. Lund, Leipzig.

Bańkowski A. 2000. Etymologiczny słownik języka polskiego. Warszawa.

Beekes R. 2010. Etymological dictionary of Greek. [2 vols.]. Leiden, Boston.

Berneker E. 1908-1914. Slavisches etymologisches Wörterbuch. [2 vols.]. Heidelberg.

Bezlaj F. 1967. Eseji o slovenskem jeziku. Ljubljana.

Bezlaj F. 1976-2007. Etimološki slovar slovenskega jezika. [5 vols.]. Ljubljana.

Blažek V. 1992. Historická analýza indoevropské zoologické terminologie (savci). [PhD Diss.]. Brno.

Blažek V. 2017. K pojmenování, medvěda' ve slovanštině. - Slavia 86: 53-60.

Boryś W. 2005. Słownik etymologiczny języka polskiego. Kraków.

Brandt R. 1889. Dopolnitel'nyja zamečanija k razboru etimologičeskago slovarja Miklošiča (prodolženije). - Russkij filologičeskij vestnik 22: 14-144.

Brückner A. 1957. Słownik etymologiczny języka polskiego. Warszawa.

Černych P.Ja. 1993. Istoriko-etimologičeskij slovar' sovremennogo russkogo jazyka. [2 vols.]. Moskva.

Damerau N. 1960. Russische Lehnwörter in der neubulgarischen Literatursprache. Berlin.

Derksen R. 2015. Etymological dictionary of the Baltic inherited lexicon. Leiden, Boston.

ESBM = Martynaŭ V.U., Cychun H.A. (eds.). 1978-2010. Etymalahičny sloŭnik belaruskaj movy. [13 vols.]. Minsk.

ESJS = Erhart A., Havlová E., Janyšková I. (eds.). 1989-2016. Etymologický slovník jazyka staroslověnského. [18 vols.]. Praha, Brno. 
ESRJ = Šanskij N.M., Žuravlev A.F. (eds.). 1963-2007. Etimologičeskij slovar' russkogo jazyka. [10 vols.]. Moskva.

ESSJ = Trubačev O.N., Žuravlev A.F., Varbot Ž.Ž. (eds.). 1974-2016. Etimologičeskij slovar' slavjanskich jazykov. Praslavjanskij leksičeskij fond. [40 vols.]. Moskva.

ESUM = Mel'nyčuk O.S. (ed.). 1982-2012. Etymolohičnyj slovnyk ukrajins'koji movy. [6 vols.]. Kyjiv.

EWA = Lloyd A.L., Springer O., Lühr R. (eds.). Etymologisches Wörterbuch des Althochdeutschen. [5 vols.]. Göttingen, Zürich.

Fraenkel E. 1962-1965. Litauisches etymologisches Wörterbuch. [2 vols.]. Göttingen.

Gebauer J. 1894-1929. Historická mluvnice jazyka českého. [4 vols.]. Praha.

Gebauer J. 1903-1916. Slovník staročeský. [2 vols.]. Praha.

Gorjajev N.V. 1896. Sravnitel'nyj etimologičeskij slovar' russkago jazyka. Tiflis.

Havlová E. 2010. České názvy savců. Praha.

Holub J., Kopečný F. 1952. Etymologický slovník jazyka českého. Praha.

Holub J., Lyer. S. 1967. Stručný etymologický slovník jazyka českého se zvláštním zřetelem k slovüm kulturním a cizím. Praha.

HR = Bernardi R., Decurtins A., Eichenhofer W., Saluz U., Vögeli M. 1994. Handwörterbuch des Rätoromanischen. Wortschatz aller Schriftsprachen, einschliesslich Rumantsch Grischun, mit Angaben zur Verbreitung und Herkunft. [3 vols.]. Zürich.

Hrinčenko B. 1907-1909. Slovar' ukrajins'koji movy. [4 vols.]. Kyjiv.

HSBM = Žuraŭski A.J., Bulyka A.M. (eds.). 1982-2012. Histaryčny sloŭnik belaruskaj movy. [32 vols.]. Minsk.

Il'jinskij G.A. 1911. Suffiks oz/ez/zz v slavjanskich jazykach. - Izvestija Otdelenija russkogo jazyka i slovesnosti Imperatorskoj Akademii nauk 16.4: 1-29.

Joki A.J. 1952. Die Lehnwörter des Sajansamojedischen. Helsinki.

KESRJ = Šanskij N.M., Ivanov V.V., Šanskaja T.V. 1961. Kratkij etimologičeskij slovar' russkogo jazyka. Moskva.

Kott F.Š. 1878-1893. Česko-německý slovník, zvláště grammaticko-fraseologický. [7 vols.]. Praha.

Králik L. 2015. Stručný etymologický slovník slovenčiny. Bratislava.

Kroonen G. 2013. Etymological dictionary of Proto-Germanic. Leiden, Boston.

Loewenthal J. 1920. Zur baltisch-slavischen Wortkunde. - Archiv für slavische Philologie 37: 377-394.

Loewenthal J. 1924. Wirtschaftsgeschichtliche Parerga. - Wörter und Sachen 9: 173-191.

Machek V. 1957. Etymologický slovník jazyka českého a slovenského. Praha.

Machek V. 1968. Etymologický slovník jazyka českého. Praha.

Matzenauer A. 1880. Příspěvky ke slovanskému jazykozpytu. - Listy filologické 7: 161-224.

Mayrhofer M. 1956-1976. Kurzgefaßtes etymologisches Wörterbuch des Altindischen. [3 vols.]. Heidelberg.

Miklosich F. 1886. Etymologisches Wörterbuch der slavischen Sprachen. Wien.

Moszyński K. 1956. Uwagi do 4. zeszytu «Słownika etymologicznego języka polskiego» Fr. Sławskiego. - Język Polski 36: 109-116.

Newerkla S.M. 2011. Sprachkontakte Deutsch - Tschechisch - Slowakisch. Wörterbuch der deutschen Lehnwörter im Tschechischen und Slowakischen: historische Entwicklung, Beleglage, bisherige und neue Deutungen. Frankfurt am Main.

Orel V. 2007-2011. Russian etymological dictionary. [4 vols.]. Calgary.

Pleteršnik M. 2006. Slovensko-nemški slovar. [2 vols.]. Ljubljana.

Pokorny J. 1959-1969. Indogermanisches etymologisches Wörterbuch. [2 vols.]. Bern, München. 
Preobraženskij A.G. 1910-1949. Etimologičeskij slovar' russkogo jazyka. [3 vols.]. Moskva, Leningrad.

PSJČ = Př́ruční slovník jazyka českého. 1937-1957. [8 vols.]. Praha.

Räsänen M. (rev.). 1953. Eine Untersuchung über die Lehnwörter des Sajansamojedischen. Joki 1952. - Anzeiger der Finnisch-Ugrischen Forschungen 31: 14-19.

Rejzek J. 2008. The Proto-Slavic word-initial $x$-. Praha.

Rejzek J. 2015. Český etymologický slovnik. Praha.

RSKNJ = Rečnik srpskohrvatskog književnog i narodnog jezika. 1959-2014. [19 vols.]. Beograd.

Rudnyc'kyj J.B. 1966-1967. An etymological dictionary of the Ukrainian language. [parts 1-5: $2^{\text {nd }}$ edition; part 6]. Winnipeg.

Šapir M. 1872. Filologičeskaja zametka o proischoždenii slov: „gornostaj“i „deševo“. Filologičeskije zapiski. Žurnal issledovanij, rassuždenij, nabljudenij i kritiki po russkomu jazyku i slovesnosti 1-2: 19-24.

Šapira D.D.Ja. 2007. Irano-slavika. Notatky ščodo irans'kych, slov'jans'kych, schidnoevropejs'kych („rus'kych“), germans'kych, tjurks'kych ta chozars'kych studij. - Ruthenica 6: 7-36.

Schrader O., Nehring A. 1927-1929. Reallexikon der indogermanischen Altertumskunde. [2 vols.; $2^{\text {nd }}$ edition]. Berlin, Leipzig.

SDRJ = Avanesov R.I., Uluchanov I.S., Krys'ko V.B. (eds.). 1988-2013. Slovar' drevnerusskogo jazyka (XI-XIV vv.). [10 vols.]. Moskva.

Šedinová H. 2015. Rejsek nebo hranostaj? Nový význam Aristotelova termínu mygalé ve středověku. - Listy filologické 138: 119-146.

Shevelov G.Y. 1964. A prehistory of Slavic. Heidelberg.

Šimek F. 1947. Slovníček staré češtiny. Praha.

SJP = Karłowicz J., Kryński A., Niedźwiedzki W. 1900-1927. Słownik języka polskiego. [8 vols.]. Warszawa.

Sławski F. 1952-1982. Słownik etymologiczny języka polskiego. [5 vols.]. Kraków.

Slepcov P.A. 1964. Russkije leksičeskije zaimstvovanija v jakutskom jazyke (dorevoljucionnyj period). Jakutsk.

SłJP = Doroszewski W. (ed.). 1958-1969. Słownik języka polskiego. [11 vols.]. Warszawa.

Smoczyński W. 2007. Słownik etymologiczny języka litewskiego. [2 vols.]. Wilno.

Sobolevskij A.I. 1962. Lekcii po istorii russkago jazyka. Moskva.

SP = Sławski F. (ed.). 1974-2001. Słownik prasłowiański. [8 vols.]. Wrocław, Warszawa, Kraków, Gdańsk.

Sreznevskij I.I. 1893-1903. Materialy dlja slovarja drevnerusskago jazyka. [3 vols.]. Sankt Peterburg.

SRJ = Barchudarov S.G., Filin F.P., Šmelev D.N., Bogatova G.A., Krys'ko V.B. (eds.). 1975-2011. Slovar' russkogo jazyka 11-17 vv. [30 vols.]. Moskva.

SRNG = Filin F.P., Sorokoletov F.P., Myznikov S.A. (eds.). 1965-2016. Slovar' russkich narodnych govorov. [49 vols.]. Moskva, Leningrad/Sankt-Peterburg.

SS = Urbańczyk S. (ed.). 1953-2002. Słownik staropolski. [11 vols.]. Wrocław, Warszawa, Kraków, Gdańsk, Łódź.

SSN = Ripka I. (ed.). 1994-2006. Slovník slovenských nárečí. [3 vols.]. Bratislava.

SSSJ = Jarošová A., Buzássyová K. (eds.). 2006-2015. Slovník súčasného slovenského jazyka. [3 vols.]. Bratislava.

Stachowski M. 1998. Dolganischer Wortschatz. Supplementband. Kraków.

Stachowski M. 1999. Konsonantenadaptation russischer Lehnwörter im Dolganischen. Kraków. SUM = Bilodid I.K. (ed.). 1970-1980. Slovnyk ukrajins'koji movy. [11 vols.]. Kyjiv.

Torbiörnsson T. 1901-1903. Die gemeinslavische Liquidametathese. [2 vols.]. Uppsala. 
TSBM = Atrachovič K.K. (ed.). 1977-1984. Tlumačal'ny sloŭnik belaruskaj movy. [2 vols.]. Minsk.

Vaan M. de 2008. Etymological dictionary of Latin and the other Italic languages. [2 vols.]. Leiden, Boston.

Vasmer M. 1953-1958. Russisches etymologisches Wörterbuch. [3 vols.]. Heidelberg.

Witkowski W. 1999. Nie tylko o gronostaju. - Mieczkowska H. (ed.). In memoriam Alfredi Zaręba et Josephi Reczek. W dziesiątą rocznicę śmierci. Kraków: 115-119.

Železnjak I.M. 1994. Slov'jans'ki antroponimni kompozyty na -staj-/-stoj-. - Movoznavstvo 1994.2-3: 39-47.

Železnjak I.M. 1995. Do etymolohiji slov. *gornostajb. - Movoznavstvo 1995.4-5: 56-63. 